\title{
Mecobalamin and early functional outcomes of ischemic stroke patients with H-type hypertension
}

Meixia Yuan

Beiyun Wang

Shijin Tan

Department of gerontology, shanghai sixth people's hospital affiliated to Shanghai Jiao Tong University, Shanghai China

http://dx.doi.org/10.1590/1806-9282.64.05.428

\section{SUMMARY}

OBJECTIVE: To analyze the effect of mecobalamin on the early-functional outcomes of patients with ischemic stroke and $\mathrm{H}$-type hypertension.

METHODS: From October of 2014 to October of 2016, 224 cases of ischemic stroke and H-type hypertension were selected. The patients were randomly divided into treatment control groups, with 112 patients in each group. The control group was treated with the conventional therapy. The observation group was treated with $500 \mu \mathrm{g}$ of mecobalamin three times a day in addition to the conventional therapy. We compared serum homocysteine (Hcy), hs-CRP levels, carotid plaques, and NIHSS scores between the two groups on the 2nd day and at 4 weeks, 8 weeks, 3 months, and 6 months.

RESULTS: After 4 weeks, 8 weeks, 3 months and 6 months, the difference of serum Hcy level between the two groups was statistically significant $(t=4.049,3.896,6.052,6.159$, respectively. All $P<0.05)$. After the treatment, at 4 weeks, 8 weeks, 3 months and 6 months, the levels of hs-CRP in the treatment group were significantly lower than those in the control group ( $t=37.249,28.376,26.454,20.522$, respectively. All $P<0.01$ ). After 3 months and 6 months, the carotid artery plaques were significantly reduced in the treatment group compared to those in the control group ( $t=2.309$ and 2.434. All $P<0.05)$. After 3 months and 6 months, the NIHSS score was significantly higher in the treatment group compared to those in the control group $(t=2.455$ and 2.193. All $P<0.05)$.

CONCLUSION: Mecobalamin can reduce the level of plasma homocysteine, then lead to reductions of levels of plasma inflammatory factors and volume of carotid artery plaques, resulting in more significant functional recovery.

KEYWORDS: Stroke. Homocysteine. Hypertension. Vitamin B 12/Analogs \& Derivatives.

\section{INTRODUCTION}

H-type hypertension is defined as hypertension with plasma homocysteine (Hcy) levels over $10 \mathrm{\mu mol}$ $/ \mathrm{L}^{1-3}$. Previous studies have shown that only $5 \%$ of the average population has an increase in plasma Hcy levels. However, in the stroke patient population, approximately $30-40 \%$ has Hcy level increases ${ }^{4}$. In addition, H-type hypertension is closely related to ischemic stroke and cerebral infarction ${ }^{5 .}$ As a com- mon neurological disease, ischemic stroke has high incidence, recurrence, mortality rates and has become a serious threat to patient's health and life in recent years. Previous studies have shown that the underlying relationship mechanism between a high plasma Hcy level and ischemic stroke is that Hcy causes inflammation and increases carotid artery plaques ${ }^{6,7}$.

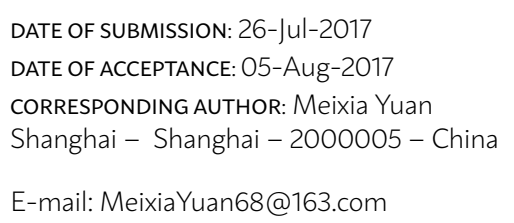


Mecobalamin (methyl-vitamin B12) belongs to the vitamin $B$ group and is one of the active analogs of vitamin B12. It is the essential cofactor for methionine synthase. Deficiency in folic acid and vitamin B12 leads to the elevation of the plasma homocysteine level, which is considered an independent risk factor in the pathogenesis of atherosclerosis ${ }^{8}$, acute myocardial infarction ${ }^{9}$, stroke ${ }^{10}$, and hypertension ${ }^{11}$. However, to date, there is no study investigating the effects of mecobalamin on the early functional outcomes of ischemic stroke patients with H-type hypertension. In the present study, in order to analyze the impact of mecobalamin on the prognosis of patients with H-type hypertension and ischemic stroke, we enrolled a total of 400 patients with H-type hypertension and ischemic stroke from October of 2014 to October of 2016. The data were analyzed and reported as follows.

\section{PATIENTS AND METHODOLOGY}

\subsection{Patients}

We selected 400 cases of hypertension and ischemic stroke from October of 2014 to October of 2016 in our hospital. Out of the patients selected, 220 were male and 180 female, with an average age of 78 . Then, 224 cases of ischemic stroke and H-type hypertension were randomly divided into the treatment and control groups, with 112 cases in each. The inclusion criteria were: (1) Age $\geq 60$ years old; (2) Blood pressure $\geq 140$ / 90mmHg; (3) Have education of junior high school or above; (4) No history of stroke; (5) No infection within 2 weeks. Exclusion criteria were: (1) Other neurological disorders that can cause dementia, such as epilepsy, Parkinson, brain trauma, intracranial tumors, infections, or toxic encephalopathy; (2) History of depression confirmed with the American Psychiatric Association Mental Disorders Diagnostic and Statistical Manual (DSM-IV); (3) Family history of other mental diseases; (4) History of alcohol and psychoactive drug abuse and dependence; (5) Use of drugs that affect brain function within two weeks.

In the treatment group, 62 patients were male and 50 were female, aged between 61 and 92, with an average of 77.8 years old. In the control group, 62 patients were male and 50 were female, aged between 62 and 79, with an average age of 78.1 years old. There was no significant difference in gender, age, and other clinical characteristics between the two groups (all $\mathrm{P}>0.05$ ).

\subsection{Methodology}

All patients in both groups were routinely given drugs to inhibit platelet aggregation, to stabilize and reduce plaques, and to improve cerebrovascular circulation and perfusion. The treatment group was treated with mecobalamin (Nippon Eisai Co., Ltd. Tokyo, Japan. Batch number: 111068) with 500 g, 3 times a day, for 6 months.

\subsection{Measurements}

All patients were drawn morning fasting venous blood on the 2 nd day, at 4 weeks, 8 weeks, 3 months, and 6 months to measure plasma levels of Hcy and hs-CRP. In addition, carotid artery plaques were measured using carotid intima-media thickness (IMT) by ultrasound examination (ATL HDI 3000 color Doppler ultrasound system, Philips Co., Ltd, Amsterdam, Holland). The carotid IMT is defined as the distance between the endometrial lumen interface and the media external membrane interface. The bilateral carotid arteries were measured at 10, 20, and $30 \mathrm{~mm}$ from the proximal end of the common carotid artery bifurcation, both for the anterior and posterior walls. A total of 12 measurement values were obtained and the average value was calculated as the IMT of the common carotid artery. IMT $<1.0 \mathrm{~mm}$ was consider normal; IMT 1.0 $\sim 1.1 \mathrm{~mm}$ was considered intimal thickening; IMT> $1.2 \mathrm{~mm}$ was considered plaque. In addition, according to ultrasound characteristics, the plaques were classified into soft, hard, and mixed. The soft plaque was defined as medium or weak echo with intimal convexing to the cavity; The hard plaque was defined as strong echo accompanied by significant sound shadow; The mixed plaque was defined as strong echo, weak or no echoes, with irregular shape and rough surface. Soft and mixed plaques are considered unstable, while hard plaque is considered stable. In addition, the National Institute of Health stroke scale (NIHSS) and Barthel index (BI) were measured ${ }^{12}$.

\subsection{Statistical analysis}

IBM SPSS 17.0 statistical software was used to analyze data. Continuous data were expressed as the mean \pm standard deviation (SD). Categorical data were expressed as percentages. All the tests were performed using a two-sided test of difference, where the inspection level $\alpha$ of 0.05 and a difference with $P$ $<0.05$ were considered statistically significant. 


\section{RESULTS}

3.1 Comparison of plasma Hcy levels before and after treatment in both groups

There was no significant difference in plasma Hcy level in the control group (all $\mathrm{P}>0.05$ ). After 4 weeks, 8 weeks, 3 months and 6 months, the difference in plasma Hcy levels between the two groups were statistically significant. The plasma Hcy levels in the treatment group were significantly lower than those in the control group $(\mathrm{t}=4.049,3.896,6.052,6.159$, respectively. All $\mathrm{P}<0.05)$. See Table 1 .

TABLE 1 THE COMPARISON OF PLASMA HCY LEVELS BETWEEN THE CONTROL AND TREATMENT GROUPS $(\mathrm{X} \pm \mathrm{S}, \mu \mathrm{MOL} / \mathrm{L})$

\begin{tabular}{|c|c|c|c|c|c|}
\hline Group & $2^{\text {nd }}$ day & $\begin{array}{l}4^{\text {th }} \\
\text { week }\end{array}$ & $8^{\text {th }}$ week & $\begin{array}{l}3^{\text {rd }} \\
\text { month }\end{array}$ & $\begin{array}{l}6^{\text {th }} \\
\text { month }\end{array}$ \\
\hline Control & $26.5 \pm 9.1$ & $27.0 \pm 8.6$ & $25.8 \pm 9.5$ & $25.7 \pm 10.2$ & $24.9 \pm 11.3$ \\
\hline Treatment & $27.0 \pm 9.2$ & $18.2 \pm 6.3$ & $16.6 \pm 6.6$ & $11.5 \pm 5.3$ & $8.6 \pm 6.2$ \\
\hline $\mathrm{t}$ & 0.189 & 4.044 & 3.896 & 6.052 & 6.195 \\
\hline p & 0.851 & 0.000 & 0.000 & 0.000 & 0.000 \\
\hline
\end{tabular}

3.2 Comparison of plasma hs-CRP levels before and after treatment in both groups

There was no significant difference in plasma hsCRP levels in the control group (all $\mathrm{P}>0.05$ ). After 2 days, 4 weeks, 8 weeks, 3 months and 6 months, the difference in plasma hs-CRP levels between the two groups were statistically significant. The plasma hsCRP levels in the treatment group were significantly lower than those of the control group $(\mathrm{t}=4.330$, 37.249, 28.376, 26.454, 20.522, respectively. All $\mathrm{P}$ $<0.05)$. See Table 2.

\subsection{Comparison of IMTs before and after treat-} ment in both groups

There was no significant difference in IMTs in the control group (all P > 0.05). After3 months and 6 months, the difference of IMTs between the two groups were statistically significant. The IMTs in the

TABLE 2 THE COMPARISON OF PLASMA HS-CRP LEVELS BETWEEN THE CONTROL AND TREATMENT GROUPS (X $\pm S, M G / L)$

\begin{tabular}{l|l|l|l|l|l} 
Group & $2^{\text {nd }}$ day & $\begin{array}{l}4^{\text {th }} \\
\text { week }\end{array}$ & $8^{\text {th }}$ week & $\begin{array}{l}3^{\text {rd }} \\
\text { month }\end{array}$ & $\begin{array}{l}6^{\text {th }} \\
\text { month }\end{array}$ \\
\hline Control & $16.5 \pm 0.25$ & $15.3 \pm 0.38$ & $14.9 \pm 0.78$ & $10.9 \pm 0.58$ & $8.9 \pm 0.69$ \\
\hline Treatment & $15.7 \pm 0.87$ & $9.9 \pm 0.6$ & $9.2 \pm 0.6$ & $6.8 \pm 0.49$ & $4.6 \pm 0.76$ \\
\hline$t$ & 4.330 & 37.249 & 28.376 & 26.454 & 20.522 \\
\hline$p$ & 0.000 & 0.000 & 0.000 & 0.000 & 0.000 \\
\hline
\end{tabular}

treatment were significantly lower than those of the control group $(\mathrm{t}=2.309$ and 2.434 , respectively. All $\mathrm{P}$ $<0.05)$. See Table 3.

\subsection{Comparison of NIHSS and BI scores before} and after treatment in both groups

After 3 months and 6 months, the difference of NIHSS and BI scores between the two groups were statistically significant. After 3 and 6 months of treatment, the NIHSS scores of the treatment group were $17.68 \pm 5.28$ and $15.45 \pm 5.45$, respectively, which were significantly better than those of the control group $(22.12 \pm 6.65$ and $20.45 \pm 5.18$, respectively). The differences were statistically significant (all $\mathrm{P}<0.05$ ). After 3 and 6 months of treatment, the BI scores of the treatment group were $82.86 \pm 10.41$ and $85.45 \pm 11.45$, respectively, which were significantly better than those of the control group (68.64 \pm 8.27 and $70.19 \pm 10.20$, respectively). The differences were statistically significant (all $\mathrm{P}<0.05$ ). See Tables 4 and 5.

\section{DISCUSSION}

Ischemic stroke is the most common type of stroke in the elderly population accounting for approximately $60-70 \%$ of all strokes, with high recurrence and mortality rates. A large number of studies have shown that high plasma Hcy level is an independent risk factor for ischemic stroke ${ }^{1,13}$. Its underlying mechanisms include participating in oxidative stress, initiating endothelial and lipid peroxidation and promoting nitric oxide synthase, thereby reducing the endothelium-derived relaxation factor, causing dysfunction of vascular endothelial cells. Serum Hcy causes damages to the blood vessels and endothelial functions, therefore decreasing the elasticity of the arterial wall ${ }^{14}$. It also can cause accumulation of calcium within vascular smooth muscle cells (VSMCs) and proliferation of VSMCs ${ }^{15}$. In addition, Hcy also

TABLE 3 THE COMPARISON OF IMTS BETWEEN THE CONTROL AND TREATMENT GROUPS $(X \pm S, M M)$

\begin{tabular}{l|l|l|l|l|l} 
Group & $2^{\text {nd }}$ day & $\begin{array}{l}4^{\text {th }} \\
\text { week }\end{array}$ & $8^{\text {th }}$ week & $\begin{array}{l}3^{\text {rd }} \\
\text { month }\end{array}$ & $\begin{array}{l}6^{\text {th }} \\
\text { month }\end{array}$ \\
\hline Control & $1.68 \pm 0.16$ & $1.45 \pm 0.39$ & $1.28 \pm 0.32$ & $1.12 \pm 0.46$ & $1.01 \pm 0.64$ \\
\hline Treatment & $1.69 \pm 0.21$ & $1.36 \pm 0.45$ & $1.12 \pm 0.60$ & $0.82 \pm 0.36$ & $0.65 \pm 0.43$ \\
\hline $\mathrm{t}$ & 0.168 & 0.673 & 1.036 & 2.309 & 2.431 \\
\hline $\mathrm{p}$ & 0.868 & 0.505 & 0.307 & 0.027 & 0.019 \\
\hline
\end{tabular}


TABLE 4 THE COMPARISON OF NIHSS BETWEEN THE CONTROL AND TREATMENT

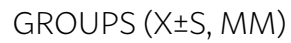

\begin{tabular}{l|l|l|l|l|l} 
Group & $2^{\text {nd }}$ day & $4^{\text {th }}$ week & $8^{\text {th }}$ week & $3^{\text {rd }}$ month & $6^{\text {th }}$ month \\
\hline Control & $28.23 \pm 5.45$ & $25.45 \pm 2.34$ & $23.28 \pm 2.45$ & $22.12 \pm 6.65$ & $20.45 \pm 5.18$ \\
\hline Treatment & $28.34 \pm 5.45$ & $26.45 \pm 4.56$ & $22.41 \pm 2.65$ & $17.68 \pm 5.28$ & $15.45 \pm 5.45$ \\
\hline$t$ & 0.145 & 0.645 & 1.045 & 2.455 & 2.193 \\
\hline$P$ & 0.845 & 0.577 & 0.345 & 0.025 & 0.024 \\
\hline
\end{tabular}

TABLE 5 THE COMPARISON OF BI BETWEEN THE CONTROL AND TREATMENT GROUPS (X $\pm S, M M)$

\begin{tabular}{l|l|l|l|l|l} 
Group & $2^{\text {nd }}$ day & $4^{\text {th }}$ week & $8^{\text {th }}$ week & $3^{\text {rd }}$ month & $6^{\text {th }}$ month \\
\hline Control & $56.23 \pm 10.34$ & $61.34 \pm 10.56$ & $71.12 \pm 10.45$ & $82.86 \pm 10.41$ & $85.45 \pm 11.45$ \\
\hline Treatment & $56.43 \pm 10.25$ & $62.36 \pm 10.81$ & $72.61 \pm 10.56$ & $68.64 \pm 8.27$ & $70.19 \pm 10.20$ \\
\hline$t$ & 0.133 & 0.383 & 1.339 & 2.292 & 2.383 \\
\hline$P$ & 0.455 & 0.577 & 0.345 & 0.018 & 0.014 \\
\hline
\end{tabular}

causes an increase in platelet adhesion and aggregation and thrombin production, therefore resulting in the formation of atherosclerotic thrombosis ${ }^{16}$.

A number of previous studies have shown that the course of hypertension is accompanied by local and systemic inflammation ${ }^{17-19}$. The previous studies have found that H-type hypertension patients are more prone to have cerebral infarction, suggesting that Hcy has a high probability of causing ischemic strokes $^{20}$. In addition, a recent study has shown that plasma Hcy level in stroke patients is significantly higher than that in a healthy population, suggesting that the plasma Hcy level is associated with an increased risk of stroke ${ }^{21}$.

In the present study, we found that plasma hs-CRP level increased in patients with H-type hypertension, indicating that the increased Hcy level is one of the causes of systemic inflammatory response in patients with H-type hypertension. The possible mechanisms of hs-CRP on carotid artery plaques are as follows.

Elevated levels of inflammation in the body lead to vascular endothelial dysfunction. Increased expression of monocyte chemoattractant protein-1 (MCP-1), endothelial cell adhesion molecules, and proinflammatory cytokines can lead to vascular inflammation, VSMCs proliferation, vascular endothelial cell injury, thus leading to plaque formation. In addition, hs-CRP can increase vascular permeability, induce VSMCs sclerosis to expand the arteriosclerosis plaque and cause leukocyte to release protease to break fibrous thrombus cap leading to thrombosis. Furthermore, hs-CRP can cause thrombosis by promoting endothelial cell-induced plasminogen inhibitor and damage arterial endothelium ${ }^{22}$. Clinical studies have found that high level of Hcy is accompanied by a high level of hs-CRP ${ }^{23}$. Therefore, drugs to reduce the level of Hcy can help reduce the level of hs-CRP in patients with H-type hypertension, which is consistent with the data of our study.

Hcy metabolic process requires cofactors including vitamin B12, vitamins B6, and folic acid, whose deficiencies will affect the activity of enzymes and the metabolic process of Hcy. A previous study has shown that there was a negative correlation between plasma Hcy level and vitamin B12, vitamin B6 and folic acid ${ }^{24}$. Therefore, the decrease in plasma Hcy level can be achieved by adding vitamin B12, vitamin B6, and folic acid in order to treat ischemic stroke.

The mechanisms of the therapeutic effects of mecobalamin are as follows: it will participate in the sulfur pathway and methylation metabolism and reduce plasma Hcy levels, which will delay cerebral artery atherosclerosis ${ }^{25}$. At the same time, mecobalamin can also effectively promote the protease, lipid and nerve tissue metabolism and myelin lipid lecithin synthesis, therefore repairing the damages to the central nervous system, improving the metabolism and transmission of nerve tissue, and ultimately promoting the functional recovery after an ischemic stroke ${ }^{26}$.

In the present study, the oral administration of mecobalamin in the treatment group effectively reduced the patient's plasma Hcy and hs-CRP levels, decreased carotid artery IMTs, and improved NIHSS and BI scores. For patients with H-type hypertension and ischemic stroke, mecobalamin treatment can not only effectively reduce the patients' plasma Hcy and hs-CRP levels, but also effectively improve the prognosis of patients. 


\section{RESUMO}

OBJETIVO: Analisar o efeito de mecobalamin sobre os primeiros resultados funcionais de pacientes com AVC isquêmico e hipertensão H-type.

MÉTODOs: De outubro de 2014 a outubro de 2016, 224 casos de AVC isquêmico e hipertensão H-type foram selecionadas. Os pacientes foram divididos aleatoriamente em grupo de tratamento e grupo controle, com 112 doentes em cada grupo. O grupo controle foi tratado com a terapia de rotina. O grupo de observação foi tratado com $500 \mu \mathrm{g}$ de mecobalamin três vezes por dia, além da rotina de tratamento. No segundo dia, 4 semanas, 8 semanas, 3 meses e 6 meses, comparamos níveis séricos da homocisteína (Hcy) e de hs-CRP, placas da carótida e pontuações NIHSS entre os dois grupos.

RESULTADOS: Após 4 semanas, 8 semanas, 3 meses e 6 meses, a diferença dos níveis séricos de Hcy entre os dois grupos foi estatisticamente significativa ( $t=4,049,3,896,6,052,6,159$, respectivamente. Todos os $P<0,05)$. Após o tratamento de 4 semanas, 8 semanas, 3 meses e 6 meses, os níveis de hs-CRP no grupo de tratamento foram significativamente inferiores aos do grupo controle ( $t=37,249$, 28,376, 26,454, 20,522, respectivamente. Todos os $P<0,01$ ). Depois de 3 meses e 6 meses, as placas da artéria carótida foram significativamente reduzidas no tratamento, em comparação com os do grupo controle $(t=2,309$ e 2,434. Todos os $P<0,05)$. Depois de 3 meses e 6 meses, as pontuações NIHSS foram significativamente mais elevadas no tratamento em comparação com as do grupo controle $(t=2,455$ e 2,193. Todos os $P<0,05)$.

CONCLUSÃo: Mecobalamin pode reduzir o nivel de homocisteína plasmática, o que conduz à redução dos níveis de plasma inflamatórios e do volume das placas na artéria carótida, resultando em maior recuperação funcional.

PALAVRAS-CHAVE: Acidente vascular cerebral. Homocisteína. Hipertensão. Vitamina B12/análogos \& derivados.

\section{REFERENCES}

1. Zhong C, Lv L, Liu C, Zhao L, Zhou M, Sun T, et al. High homocysteine and blood pressure related to poor outcome of acute ischemia stroke in Chinese population. PLoS One. 2014;9(9):e107498.

2. Malinow MR, Bostom AG, Krauss RM. Homocyst(e)ine, diet, and cardiovascular diseases: a statement for healthcare professionals from the Nutrition Committee, American Heart Association. Circulation. 1999;99(1):17882.

3. Sacco RL, Adams R, Albers G, Alberts MJ, Benavente O, Furie K, et al; American Heart Association; American Stroke Association Council on Stroke; Council on Cardiovascular Radiology and Intervention; American Academy of Neurology. Guidelines for prevention of stroke in patients with ischemic stroke or transient ischemic attack: a statement for healthcare professionals from the American Heart Association/American Stroke Association Council on Stroke: co-sponsored by the Council on Cardiovascular Radiology and Intervention: the American Academy of Neurology affirms the value of this guideline. Stroke. 2006;37(2):577-617.

4. Ganguly P, Alam SF. Role of homocysteine in the development of cardiovascular disease. Nutr J. 2015;14:6.

5. Graham IM, Daly LE, Refsum HM, Robinson K, Brattström LE, Ueland PM, et al. Plasma homocysteine as a risk factor for vascular disease. The European Concerted Action Project. JAMA. 1997;277(22):1775-81.

6. Weiss N. Mechanisms of increased vascular oxidant stress in hyperhomocys-teinemia and its impact on endothelial function. Curr Drug Metab. 2005;6(1):27-36

7. Abahji TN, Nill L, Ide N, Keller C, Hoffmann U, Weiss N. Acute hyperhomocysteinemia induces microvascular and macrovascular endothelial dysfunction. Arch Med Res. 2007;38(4):411-6.

8. Kerkeni M, Addad F, Chauffert M, Chuniaud L, Miled A, Trivin F, et al. Hyperhomocysteinemia, paraoxonase activity and risk of coronary artery disease. Clin Biochem. 2006;39(8):821-5

9. Banu S, Mollah FH, Alam MK, Rahman MA, Hamid MA, Wahab MA, et al. Serum homocysteine concentration in patients with acute $\mathrm{MI}$ and chronic IHD. Mymensingh Med J. 2005;14(1):54-7.

10. Torbus-Lisiecka B, Bukowska H, Jastrzebska M, Chelstowski K, Honczarenko K, Naruszewicz M. Lp(a), homocysteine and a family history of early ischemic cerebral stroke. Nutr Metab Cardiovasc Dis. 2001;11( Suppl 5):52-9.

11. Kahleová R, Palyzová D, Zvára K, Zvárová J, Hrach $\mathrm{K}$, Nováková I, et al. Essential hypertension in adolescents: association with insulin resistance and with metabolism of homocysteine and vitamins. Am J Hypertens. 2002;15(10 Pt 1):857-64.

12. Bonita R, Beaglehole R. Recovery of motor function after stroke. Stroke. 1988;19(12):1497-500.

13. Kwon HM, Lee YS, Bae HJ, Kang DW. Homocysteine as a predictor of early neurological deterioration in acute ischemic stroke. Stroke. 2014;45(3):871-3.
14. Markišić M, Pavlović AM, Pavlović DM. The impact of homocysteine, vitamin B12, and vitamin D levels on functional outcome after first-ever ischaemic stroke. Biomed Res Int. 2017:5489057.

15. Zhao M, Wang X, He M, Qin X, Tang G, Huo Y, et al. Homocysteine and stroke risk: modifying effect of methylenetetrahydrofolate reductase C677T polymorphism and folic acid intervention. Stroke. 2017;48(5):118390.

16. Xu B, Kong X, Xu R, Song Y, Liu L, Zhou Z, et al. Homocysteine and allcause mortality in hypertensive adults without pre-existing cardiovascular conditions: effect modification by MTHFR C677T polymorphism. Medicine (Baltimore). 2017;96(8):e5862.

17. Nosalski R, McGinnigle E, Siedlinski M, Guzik TJ. Novel immune mechanisms in hypertension and cardiovascular risk. Curr Cardiovasc Risk Rep. 2017;11(4):12

18. Rudemiller NP, Crowley SD. The role of chemokines in hypertension and consequent target organ damage. Pharmacol Res. 2017;119:404-11.

19. Park HK, Kwak MK, Kim HJ, Ahima RS. Linking resistin, inflammation, and cardiometabolic diseases. Korean J Intern Med. 2017;32(2):239-47.

20. Chen Z, Wang F, Zheng Y, Zeng Q, Liu H. H-type hypertension is an important risk factor of carotid atherosclerotic plaques. Clin Exp Hypertens. 2016;38(5):424-8

21. Jia J, Wang A, Wang J, Wu J, Yan X, Zhou Y, et al. Homocysteine and its relationship to asymptomatic carotid stenosis in a Chinese community population. Sci Rep. 2016;6:37361.

22. Corrado E, Rizzo M, Coppola G, Fattouch K, Novo G, Marturana I, et al. An update on the role of markers of inflammation in atherosclerosis. J Atheroscler Thromb. 2010;17(1):1-11.

23. Gong $X$, Zou X, Liu L, Pu Y, Wang Y, Pan Y, et al. Prognostic value of inflammatory mediators in 1-year outcome of acute ischemic stroke with middle cerebral artery stenosis. Mediators Inflamm. 2013;2013:850714.

24. Toole JF, Malinow MR, Chambless LE, Spence JD, Pettigrew LC, Howard $\mathrm{VJ}$, et al. Lowering homocysteine in patients with ischemic stroke to prevent recurrent stroke, myocardial infarction, and death: the Vitamin Intervention for Stroke Prevention (VISP) randomized controlled trial. JAMA. 2004;291(5):565-75

25. Ebbing M, Bønaa KH, Arnesen E, Ueland PM, Nordrehaug JE, Rasmussen $\mathrm{K}$, et al. Combined analyses and extended follow-up of two randomized controlled homocysteine-lowering B-vitamin trials. I Intern Med. 2010;268(4):367-82.

26. Cavalieri M, Schmidt R, Chen C, Mok V, de Freitas GR, Song S, et al. $B$ vitamins and magnetic resonance imaging-detected ischemic brain lesions in patients with recent transient ischemic attack or stroke the VITAmins TO Prevent Stroke (VITATOPS) MRI-substudy. Stroke. 2012:43(12):3266-70 